\title{
The Impact of Lord Burghley and the Earl of Leicester's Spanish-Speaking Secretariats
}

\author{
Hannah Leah Crummé \\ University College London | King's College London
}

\begin{abstract}
Whilst the literature of the Spanish Golden Age is itself filled with problems of representation, I will argue in this paper that the greatest misrepresentation of all did not occur in fiction but rather in the English court. During Elizabeth's reign Lord Burghley, working with his secretary Sir Francis Walsingham, systematically misrepresented Spanish culture, deliberately obscuring the English perception of Spanish Golden Age and casting over it a veil of fear. The Earl of Leicester, by contrast, working only to improve his own reputation as a literary patron and man of letters, inadvertently increased English access to Spanish literature as he patronized a coterie of Spanish-speaking scholars at the University of Oxford. These Spanish secretaries translated Spanish literature and created Spanish dictionaries. By analysing the propaganda created under Burghley and the dictionaries created under Leicester, I will show how the English perception of the Spanish Golden Age developed. How, one might ask, was Antonio del Corro's arrival at the university tied to the printing of the first Spanish books in England at the university press? Why did both Leicester and Burghley eventually sponsor Spanish-English dictionaries? How did these different media and dictionaries mediate the English perception of Spain? These are some of the questions my paper will address through examination of the Atye-Cotton manuscripts (now housed at the British Library), a series of pamphlets sponsored by Lord Burghley, and several English-Spanish dictionaries created in the late $16^{\text {th }}$ century.
\end{abstract}

KEYWORDS: Essex, Burghley, Leicester, secretaries, dictionary, Spanish. 


\section{The impact of Lord Burghley and the Earl of Leicester's Spanish-speaking secretariats}

Under Elizabeth I England's relationship with Spain shifted dramatically. Interest in Spanish language and literature that had flourished under Catherine of Aragon and continued in the reign of (Catholic) Mary was suddenly replaced with suspicion under Protestant Elizabeth (Ungerer 1965:178). Elizabeth's most trusted advisors influenced her foreign policy. Under these courtiers a dichotomy developed. During the 1580s the English relationship with Spain was influenced by Lord Burghley, who, as secretary of state, sponsored pamphlets which encouraged the English fear of war and Spanish cruelty. Meanwhile, the Earl of Leicester, motivated by a desire to cultivate a reputation for sophistication, sponsored Spanish works, giving rise to an academic trend at the University of Oxford that lead to the printing of Spanish books in Elizabethan England. ${ }^{1}$

In 1569 Lord Burghley warned the English court that Spain was uniting with France (in obedience to papal command), in preparation for an attack on England (MacCaffrey 2010). Burghley's warning marked the beginning of a battle for public opinion: by the time of the first military encounter with the Spanish Armada in 1588 English markets were saturated with anti-Spanish propaganda. Lord Burghley promoted Elizabeth's defensive stance towards Spain and encouraged the development of an English aversion to Spain. The recipient of most of the intelligence that came into England from the continent, Burghley used a large Spanish-literate secretariat to circulate manuscript letters strategically in court while he hired pamphleteers to create terrifying Spanish threats which they then answered with English propaganda. In the continuation of a now familiar trope of the English Renaissance, Leicester thus found himself in opposition to Burghley. Leicester and later Essex both anticipated war, something which seems to have mitigated any fear of the Peninsula Leicester might otherwise have laboured under. In

\footnotetext{
${ }^{1}$ William Cecil was created first Baron Burghley on 5 February 1571 by Queen Elizabeth. Regardless of this late date I will refer to him throughout this paper as Burghley for convenience. Robert Dudley was created Earl of Leicester in September 1564; similarly, he is referred to throughout as Leicester.
} 
any case, Leicester patronized many Spanish projects, including several Spanish dictionaries, with apparently no concern for the potential problems that familiarizing an English readership with Spanish culture might cause. Using a secretariat made up of scholars and translators, Leicester selectively reintroduced Spanish literature to early modern England. Both Leicester and Burghley acted as patrons for scholars who created Spanish-English dictionaries. Leicester's dictionaries allowed English speakers to interact with Spanish literature in a way that was essentially unmediated, developing an organic relationship with Spanish through literature, rather than the highly cultivated opinions created by Burghley's pamphlets. Burghley, however, identified the persuasive power of the dictionary itself and hired men capable of creating the very biased Dictionary in Spanish and English.

Leicester and Burghley's shared interest in Spanish created employment for Spanish speakers in England. While Leicester's patronage gave rise to a coterie of scholar-secretaries at Oxford, Burghley surrounded himself with rough-and-ready Spanish speakers who poured libels from the presses of London. By examining the propaganda and dictionaries created by Elizabeth's most trusted advisors, I will argue that this secretariat was responsible for creating the Elizabethan relationship with Spanish literature.

\section{Lord Burghley and Sir Francis Walsingham, and their pamphlets}

Lord Burghley's efforts had by far the greatest impact on the English perception of Spain in the 1580 os. The propaganda he produced began the establishment of the "black legend" that coloured English relations with Spain for the coming century. Burghley engaged Spanish-speaking pamphleteers and translators who poured out libels against the enemy, creating an English fear of Spain that the failed invasion of 1588 solidified. Assisted by his own secretary, Sir Francis Walsingham, Burghley shaped public opinion regarding Spain almost exclusively through pamphlets. The extent of Burghley's mediation of the English picture of Spain demands a study in itself: As secretary of state Burghley was in charge of a large network of spies across Europe and in Spain that fed information to 
the court. This article, however, focuses on the impact made by Burghley's two personal Spanish-speaking secretaries: Walsingham and Richard Perceval. ${ }^{2}$ This detailed examination makes an excellent case study of the printed material Burghley circulated about Spain, first in pamphlets and then through dictionaries.

La Respuesta exemplifies the Spanish works created by Walsingham and Burghley. Written in 1588 apparently on behalf of the English Government by an anonymous Spanish immigrant, the Spanish pamphlet was licensed for printing under Walsingham's authority. Eventually translated by James Lea and titled An Answer to the Untruths Published in Spaine, the Answer so closely resembles other letters purportedly written by Spanish expatriates and issued by Burghley and Walsingham that it throws doubt on the letters' authenticity (Ungerer 1965:194). Ungerer points to the similarity between the Answer and A Copie of a Letter Sent out of England to Don Bernardin Mendoza. ${ }^{3}$ Burghley likely produced the manuscript himself: an early draft of the letter is written in his own hand, with some indication that it has been edited by Walsingham (Lea 1589:A3r). ${ }^{4}$ Beginning with the English relationship with the Catholics, both tracts focus on Sir Francis Drake's naval prowess and the inefficacy of Spanish propaganda. The two pamphlets praise Burghley and Walsingham's work, congratulating the English on the quality of their intelligence from the continent and lamenting the demoralizing effect the circulation of Spanish letters (like the Answer and the Copie) had on the Armada in the run-up to 1588. In particular, the Answer explains that "There was [...] such kind of other bookes printed in Spaine containing particular long descriptions, and catalogues of Armados of Castile [...] and detailing all the Spanish naval resources," which led to the Spanish defeat $(A$ copie of the letter sent out of England 1588:7). In The Copie the author, or authors, (probably both jointly Walsingham and Burghley) makes clear that any Spanish propaganda that circulates in England only

\footnotetext{
${ }^{2}$ Alan Smith's 1968 article in The English Historical Review masterfully details the lives and duties of the Cecils' personal secretaries but does not address the role of either Walsingham or Perceval in the production of Spanish dictionaries.

${ }^{3}$ S.T.C. 17131 and A copie of the letter sent out of England to Don Bernardin de Mendoza Ambassador in France for the King of Spaine 1588. S.T.C. 15412.

${ }^{4}$ London, British Library, MS Landsdowne, 03, folio 55. I am thankful to Gustav Ungerer for this reference.
} 
motivates the English further, essentially declaring the efficacy of Burghley's efforts. According to the Copie,

no one thing hath done at this time more hurt to the action [of the Armada] than the hastie publishing in this realme before this Armie of Spaine was readie to come forth to the seas, of sundry things put in print, and sent into this realme to notifie to the people that all the realm should be invaded and conquered, that the Queen should be destroyed, all the Nobilitie and the men of reputation that did obey her or that wold withstand the invation, should be with their families rooted out and in their places their houses and lands bestowed upon the conquerors: things universally so odiously taken, as the hearts of all sorts of people were enflamed: some with ire, some with fear, but all sorts almost without exception resolved to venture their lives for the withstanding of all manner of conquest. (A copie of the letter sent out of England 1588:7)

The Copie thus highlights the complexity of Burghley's plan: the Spanish, it is claimed, lament how their propaganda has motivated the English to fight. By creating such a letter Burghley and Walsingham account for any past or future failures to stop the spread of Spanish propaganda. When paired with the Answer the momentum of Burghley's campaign becomes clear. For while the "Spanish" author of the Copie is alarmed at how Spanish propaganda motivates the English, the Answer clarifies that the propaganda that motivated the English was in fact Spanish lies. The Answer responds to Diego Perez, postmaster of Logroño, saying:

Your honor saith, that if [Drake] be not prisoner he is slaine, in these words. Drake is either taken or dead. Yet if [Drake's] enimie fled from him, who tooke him or slue him? If your Honor in saieng Drake is prisoner or dead then added he is prisoner to her majestie, then I would be silent, for that he is so loyall a subject unto her, that, though free, yet waites in her prison, and sacrificed day and night to do her service. In saieng dead, had your Honor named the disease whereof he died, we would saie that howre come, wherein the Lord Almighty had called him unto himself: but finally he is both free and alive, and as loyall a vassal to her majestie as ever. (Lea 1589:3)

Burghley paints a picture of thoughtful Englishmen who recognize the duplicity of their enemy and thus are spurred on by Spanish propaganda to hate rather than fear their enemy. Together Walsingham and Burghley create a detailed model for the English 
reception of Spanish, and in so doing draw heavily on material they attribute to Spanish sources, a tactic that would become common in the pamphlets produced by Burghley's secretariat and later would be rather ungracefully imitated by Essex.

These pamphlets created by Burghley and Walsingham intended to rouse English feelings against the Spanish also included A True Discourse of the Assault Committed upon the Person of the Most Noble Prince, William Prince of Orange ${ }^{5}$ (Jáuregui y Aguilar 1582), Ad Serenissimam Elizabetham Anglaie Reginam Theodor ${ }^{6}$ (Béze 1588), A Libell of Spanish Lies: Found at the Sacke of Cales, discoursing the fight in the West Indies ${ }^{7}$ (1596), and The Opinion of Don Alvaro Bacan, Marques of Santa Cruz, and High Admirall of Spaine, touching the armie of Sir Francis Drake ${ }^{8}$ (Bazan 160o). Works commissioned through Walsingham appeared almost entirely before the 1596 sack of Cadiz. ${ }^{9}$

\footnotetext{
${ }^{5}$ S.T.C. 25713.

${ }^{6}$ S.T.C. 1998.

7 S.T.C. 6551 . This pamphlet is attributed to Henry Saville but appears to be a translation from Bernaldino Delgadillo de Avellaneda's Copia de una Carta. According to Ungerer, the copy was acquired by Saville, captain of the H.M.S. The Adventure, who had it translated into English and wrote the answer himself.
}

${ }^{8}$ S.T.C. 12626 . Both the Spanish and English texts of this work were included in Richard Hakluyt's Principal Navigations (1600 3.530-534).

${ }^{9}$ After the sack of Cadiz Essex began a pamphleteering project that rivalled the scale of that of Burghley, though it lacked the subtlety and skill of Walsingham. Essex, responsible himself for looting the library of the Bishop Mascarenhas at Faro, answered the widespread criticism of his campaign in lively terms. In a volume held in the British Library some of the more interesting pamphlets cultivating the English relationship with Spain are bound-together. Most are not mentioned by Ungerer as they do not include any Spanish texts, instead addressing the Spanish in English (though at least one claims to be "translated out of Spanish into English by T.P"). Two short pamphlets at the end of the compilation respond to the Cadiz episode. The first of these is entitled A Declaration of the Causes Moving The Queenes Majestie of England. Printed by Christopher Barker, printer to the Queen, this pamphlet seems to stand alone as a defence of the attack upon Cadiz issued by the court. The second and much shorter defence of Cadiz included in this volume appears under the authority of the Earl of Essex and Charles Howard, Earl of Nottingham. This three page declaration by the Earl of Essex definitively identifies him as commander of the Queen's navy and explains the attack on Cadiz as the only possible defence of Ireland. Clearly written both to appease the Queen and to justify his own actions, Essex declares the necessity of the campaign, characterizing the English as sorely put upon by their Spanish adversaries. A Libell of Spanish Lies was likely also created at Essex House. Following the format of A Packe of Spanish Lyes, a Spanish writer is refuted with facts presented by an English writer. The pamphlet explains that the report of Drake's death was "altogether received for an undoubted truth [in Spain], and so pleasing was this news 
Burghley's defensive stance towards Spain may explain the emphasis on dishonesty that dominates in this propaganda (and is entirely lacking in literature patronized by Essex or Leicester). The True Discourse details the escape of Spanish assassins together with "writinges, depositions, examinations and letters of sundrie heinous offenders" as well as "wicked and cruel deedes," showing that "all the Spaniards in the worlde" could not contradict the author (Jáuregui y Aguilar 1582:14). The pamphlet makes clear that it was only through trickery that the Spanish surprised the Prince of Orange. Emphasizing the cowardice and villainy of the Spanish, the True Discourse produces exactly the Spanish enemy Burghley desires (Jáuregui y Aguilar 1582:16). This characterization will be the unifying factor between the propaganda produced under Burghley by Walsingham in the 1580 o and early 1590s, and the dictionary created by Perceval and John Minsheu under Burghley in 1599.

The most structurally interesting example of this propaganda by Burghley's secretariat is a pamphlet entitled A Packe of Spanish Lyes, Sent Abroad in the World. This small book is printed in two columns, one claiming to be an English translation of "A packe of Spanish Lyes" and the other an answer "from England" (1588:2). The English retorts re-iterate the dishonesty of the Spaniard, as each English response begins with "Here followeth the mountaine of lies" or "All these untrue newes are sayed to have come from the Spanish fleete." ${ }^{\prime 10}$ The Packe of Spanish Lyes, bears an even closer resemblance to An Answer than the Copie does, reiterating that the purpose of the pamphlet is to some extent to contradict the reports of the postmaster of Logroño (1588:2). Although no other Elizabethan pamphlets regarding Spain and Spanish treachery are formatted in two columns in this fashion, both An Answer and the later A Libell of Spanish Lies use Burghley's signature tactic of printing apparently

unto the Spaniard that there was present commandment given to publish the letter in print. [...] The letter came to the hands of Henrie Savile, Esquire, who being employed in that service [...] hath caused the said printed letter to be translated into English. And that impudence of the Spanish Generall may be the more plainely appear, the said Henrie Savile doth answer particularly to everie untruth in the same letter contained."

${ }^{10}$ The British Library's edition of this pamphlet is bound with Orders set Downe by the Ducke of Medina, Lord General of the Kings Fleet, to be Observed in the Voyage towards England (1588). Printed by Thomas Orwin, this pamphlet claims to be "translated out of Spanish into English by T.P." 
Spanish letters then meeting them with an English answer. Unlike An Answer, A Packe takes what it claims are direct quotations from "a letter of Diego Perez" and responds to them. The two together offer an interesting model of the self-generation of Burghley's secretaries' work: if Diego Perez's letter is in fact an authentic document, it would have been delivered directly to Burghley from one of his agents in Spain. It would also have been at Burghley's discretion that the letter was translated, and at his order that it received a relatively large-scale response from London pamphleteers. Thus the claim that Drake was killed in the 1588 battle with the Spanish Armada is created in England by Burghley's agents, then reprinted in the Packe of Spanish Lyes along with the claim that the Spanish had "sunke two and twentie shippes and taken fourtie," creating the opportunity for his secretariat to respond with further pamphlets and letters praising Drake's prowess (1588:2).

Burghley and Walsingham worked tirelessly to cultivate a distrust of Spain. Their task became more complex after the sack of Cadiz led by the Earl of Essex in 1596, flooding the English court with Spanish loot, including books from some of the largest Spanish libraries. ${ }^{11}$ The sudden influx of literature from a papist country, uncontrolled by Burghley and his agents, was a matter of concern: Sir Robert Cecil was warned by one of his Spanish-speaking sources that "there hath been brought from Cadiz, by sundry persons, a great number of printed books, as well Latin and Spanish, of which although some may be used, no doubt there are others that may do very much hurt." ${ }^{\prime 2}$ After 1596 Burghley and Walsingham seem to have stopped creating pamphlets: Burghley's place as a promoter of propaganda was quickly filled by the Earl of Essex, who began to work tirelessly to defend his actions at Cadiz. Confident that Elizabeth would not take further aggression against Spain, Burghley continued to gather intelligence from the Peninsula, but significantly reduced his patronage of "Spanish" works. An exception to this policy seems to have been his promotion of a dictionary with such a bias that it ensured long term hostility towards Spain: thus it was

\footnotetext{
${ }^{11}$ The topic of the books that entered England after the sack of Cadiz deserves a study in itself. Ungerer gives a partial description of which Spanish libraries were raided, who took books, and which Spanish books entered England.

${ }^{12}$ Hatfield Papers (1895, vi.375). The majority of these books are now housed in the Bodleian Library.
} 
that Burghley brought the most successful English-Spanish lexicographer in England into his employ. It seems likely that Burghley's decision to encourage the work of Perceval and Minsheu was made in response to the success of the dictionaries patronized by Leicester. For just as Burghley cultivated an English distaste for Spain, Leicester's soft diplomacy, likely intended as self-promotion rather than in support of Spain, was re-popularizing the study of Spanish at both the universities and the court.

\section{The Earl of Leicester and the Oxford Hispanists}

Vernacular languages were not formally taught at either university in Elizabethan England. Yet although no one at either Oxford or Cambridge officially studied Spanish, the two universities produced a number of scholars, statesmen, translators, and tutors who were well versed in the language. Appointed chancellor of Oxford in 1564, Leicester was determined to utilize the university to advance his reputation as a scholar and patron of learning.

Early in his career Leicester took an interest in foreign language dictionaries. He patronized Thomas Cooper's Thesaurus in 1565. The success of this dictionary kept Leicester's name prominently in the book-buying public sphere and created an association between Leicester's patronage and lexicons (Rosenberg 1588:2). Leicester went on to support both classical and vernacular dictionaries and grammars. Amongst these were the many successive editions of John Whithals' Short Dictionarie. Established as one of the primary texts used in Elizabethan grammar schools, the Short Dictionarie was heavily revised and augmented by Lewis Evans. In 1579 Evans thanked Leicester for his past generosity, indicating Leicester's longterm patronage of the work (Withals 1579). ${ }^{13}$ In 1581 Edward Grant dedicated to Leicester his Lexicon Graeco-latinum, an edition of the Greek-Latin dictionary compiled by Jean Crespin. It is noteworthy that even Grant, a special protégé of Burghley, sought Leicester's patronage for his learned dictionary: Grant explains his decision, mentioning the Earl's sponsorship of Cooper's successful thesaurus and likening it to his lexicon. Beyond these Latin lexicons, Leicester consistently and enthusiastically supported vernacular dictionaries

${ }^{13}$ S.T.C. 2588 o. 


\section{H. L. Crummé}

and grammars. In 1578 John Florio dedicated his Italian language book Firste Fruites to him, and both Antonio del Corro and Thomas D'Oyley produced Spanish-language books while under his patronage as scholars at Oxford.

Unlike Burghley, who was himself responsible for some of the Spanish works published under him, Leicester did not compose any "Spanish" works, treatises, or translations. Although Leicester's protégés, secretaries, and scholars compliment Leicester's knowledge of languages, Eleanor Rosenberg argues that while Leicester had an enthusiasm for learning, he had little skill in any language except English (Rosenberg 1955:151). A passage from a letter addressed to the earl indicates the degree to which Leicester's secretaries mediated his interactions and the impact his secretariat had on Leicester's image:

[...] it is needless to give you exquisite precepts, because you have attending upon you one for the same purpose, sufficiently furnished, the benefit of whose service you have in use [...] if he be such a man indeed, as by your letters unto me directed and delivered, I do gather. (Rosenberg 1955:160)

This letter, which likely refers to Atye's skill in translating Leicester's correspondence into several languages, indicates how important Leicester's multilingual secretariat was, both to his ability to act as a statesman and to language study at English universities and at court.

Elizabeth encouraged Leicester to establish a substantial retinue when he was made an earl, which dramatically increased the secretariat in his employ. Almost all of Leicester's secretaries were drawn from either Oxford or Cambridge: Edmund Spenser, Edward Dyer, Edmund Campion, and Gabriel Harvey would all eventually serve the Earl as secretary. ${ }^{14}$ However, although Leicester found his secretaries at both universities, he installed them almost exclusively at Oxford. In so doing Leicester not only founded the study of Spanish at the university, but this also led directly to the first complete Spanish book printed in England, a work that contributed to the wide-spread proliferation of Spanish in England at the end of the $16^{\text {th }}$ century.

${ }^{14}$ Leicester's secretariat deserves far more attention than the length of this paper allows. 
Antonio del Corro became the centre of a coterie of Hispanists in Oxford under Leicester, becoming the most prominent authority on the Spanish language at the university at this time. He came to England as a Spanish expatriate and ex-clergyman, arriving in 1567, twenty years after he had renounced Catholicism and left Spain to join the European courts as a Spanish instructor (Gordon 2010). Both Burghley and Leicester supported Corro as he became the pastor to London's recently disenfranchised Spanish congregation. The congregation was in disarray due to the recent flight of Casidoro de Reina, their pastor: Corro's arrival revived it. Only briefly accepted as a clergyman in London due to persistent doubts about the orthodoxy of his views, a conflict that would plague Corro began only shortly after his arrival in England. Corro responded to these doubts in seven letters addressed to Benza at Geneva, who transferred mediation of the conflict to Bishop Grindal (Gordon 2010). Grindal suspended Corro in 1569 for slander and obstinacy; Corro was not reprimanded for any doctrinal aberration. Burghley's support faded as Corro became an increasingly controversial figure. Corro's apparent inability to make friends in London made Leicester's eventual success installing him at Oxford all the more important for Corro's career.

On 5 March 1576 Leicester sent letters to the vice-chancellor and convocation of Oxford asking that Corro precede Doctor of Theology without fee (Foster 1891:44). By April the convocation granted the request on condition "that he purge himself of heretical opinions" (McFadden 1955:455). Corro reiterated his support for a conventional Protestant doctrine and was on track to enter the university, but controversy slowed his progress and it ultimately took Leicester two more years of campaigning before Corro was finally admitted to Oxford in the summer of 1578 as censor theologicus at Christ Church. Corro matriculated as a member of the college in 1586 (Foster 1891:44). Corro's relationship with his English patrons highlights the difference between Leicester and Burghley's sentiment towards Spaniards in England, for while Leicester continued to support Corro enthusiastically, Burghley not only withdrew his support but also apparently developed a deep suspicion of him. During Corro's later time at Oxford, Burghley used his complex intelligence network to keep track of the Spaniard. Burghley's associate William Davidson, ambassador to the Netherlands, employed Burghley's brother-in-law Sir Henry Killigrew (at the time one of Leicester's 
secretaries), to report regularly on Corro, and the information Davidson collected was almost certainly relayed to Burghley (Rosenberg 1955:151). The suspicions surrounding Corro, as well as his own combative nature, created an obstacle to his publication of theological work and ended his hope of returning to his life as a clergyman in London. Instead Corro published the first Spanish grammar in England at the University press and successfully lectured on both theology and Spanish language for over a decade.

Of the many men supported by Leicester, Corro's work had the greatest impact on the study of Spanish in England. His Reglas Gramaticales was the first book printed entirely in Spanish in Elizabethan England in 1586. Printed by Joseph Barnes at the university's press, Reglas was dedicated to Leicester's friend, the Italian expatriate Sir Horatio Palavicino, but was a product of the position Leicester had made available to Corro. New to printing, Barnes was known for the avant-garde works he printed, for which he found a good market in Oxford. He produced various vernacular works in 1586 during his first year as the university's printer. Barnes was no fool: his decision to print Corro's Reglas was almost certainly a response to an increasing interest in Spanish at the university over the previous decade. As a bookseller himself, Barnes knew what demand existed at the university, and likely decided to go ahead with the edition after receiving requests for Spanish books from pupils of Corro and the other Spanish speakers at Oxford, including Arthur Atye, John Therie, and Thomas D'Oyley. Though the work was printed exclusively at Oxford, some of the editions appeared with a false Paris imprint and were sold on the continent, probably as a means of increasing Barnes' return on his investment. The Spanish language guide had far better hopes for successful sales on the continent. Only the Oxford-imprint versions of the book contained the dedication to Palavicino, indicating an expectation that the edition would circulate with at least some popularity in England, and that it would circulate not only at Oxford but also at court.

Four years later Corro followed the Reglas with his The Spanish Grammer, a guide to the Spanish and French language. Entered in the stationers' register on 7 April, the book was dedicated to John Whitgift, Archbishop of Canterbury. In this version, adapted for English speakers by Corro's pupil John Therie, Corro claimed that the book was "snatched from [his] hands by some friends of Joseph 
Barnes," and it does indeed seem likely that Corro had not intended it for publication in England (Ungerer 1965:197). Before Therie's modifications The Spanish Grammer was almost entirely inaccessible to English students. Therie translated explanations of Spanish grammar into English from both French and Spanish, but unfortunately he chose to leave all the examples throughout the book in French. Rather than translating the French examples to English, which would have greatly simplified the guide, Therie added a dictionary to make the Spanish examples used in the book accessible to English speakers. This choice made the Grammer the first English/Spanish dictionary printed under Elizabeth. Despite Therie's modifications the work remained so confusing that John Wolfe, the edition's printer, saw fit to use different typefaces to distinguish between English, French, and Spanish. After publishing Corro's work Barnes did not return to works in the Spanish language. However, John Wolfe took up the torch, printing a number of works over the subsequent decade composed by the Oxford Hispanists. Barnes' publication of Corro opened the door to printing in Spanish in Elizabethan England and his efforts, combined with those of Corro and Leicester's other Spanish speaking Oxford scholars, became a kind of soft diplomacy set in opposition to Burghley's loud propaganda. In the year following the publication of Corro's (and Therie's) Grammer, another Spanish dictionary originating in Oxford was entered in the stationers' register by Joseph Barnes for Thomas D'Oyley. Either D'Oyley's work was never printed or it does not survive, though traces of it can be found in Perceval's work (1591). ${ }^{15}$ Arthur Atye was the only prominent

\footnotetext{
${ }^{15}$ Perceval's Bibliotheca Hispanica asserts its superiority over "any that have gone before." Perceval implies that his dictionary is better because he is an Englishman who speaks Spanish, rather than a native Spanish speaker, as "those things that to [him] being a straunger to the toonge, appeared upon good reason to bee worth the observation: were so ordinarie with them, as they seemed needless to be drawen into rule." However, Perceval claims that he is "not so malicious as to detract from the labours of any that have gone before; but confesse, that [I] have both seene and used them where [I] thought it convenient." Perceval acknowledges a number of sources, maintaining that only 2000 of the words in the dictionary are his own. He explains that he met Thomas D'Oyley at a very fortuitous moment, just before he sought publication for his dictionary. He claims that although D'Oyley had "begunne a Dictionary in Spanish, English, and Latin," he saw that Perceval was "more forward to the press than himself [and so] very friendly gave his consent to the publishing of [Perceval's], wishing [him] to adde the Latine as hee had begunne in his; which [he] performed, being not a little furthered therein by [D'Oyley's] advise and conference." While Perceval provides an appealing description of the scholarly community
} 
Spanish-speaking scholar under Leicester's employ at Oxford who did not eventually produce a Spanish dictionary. Unlike the works produced under Burghley the dictionaries from Oxford were relatively unbiased, creating a means of accessing Spanish literature without significant mediation. Although the proliferation of dictionaries under Leicester created this new access to Spanish in England, Burghley would waste little time before he modified the genre to suit his purposes. Leicester himself had little opportunity to learn the language and use dictionaries, so instead he employed his own mediators: Arthur Atye became the primary means through which the Earl accessed works in Spanish.

Atye, Leicester's primary secretary in the last two decades of his life, was one of Oxford's most prominent Spanish-speakers. Much before he was introduced to the University as a lecturer, Atye had received his BA from Christ Church in 1561 and his MA from Merton in 1562 (Foster 1891:64). There is no evidence that Atye had any knowledge of Spanish during his time as a student, but when the opportunity arose he attended the warden of Merton, John Man, on his embassy to Spain between 1566 and 1568 (Adams 1993:132). After this expedition Atye possessed a proficient command of Spanish that ultimately proved one of his primary assets in his service of Leicester. ${ }^{16}$ Atye's expedition with Man, as well as most of his training at Oxford, seems to have been aimed at building a career in London, yet - Simon Adams observes - Atye possessed the innate qualities that made him an academic. Adams' claim seems to hold true (Adams 1993:132). Leicester frequently chose to keep Atye at Oxford rather than have him resident at Leicester House; Atye remained at the university even at times while he was serving as chief secretary (above up to six subsidiary secretaries).

studying Spanish in the 1590s, it is unlikely that it represents the complete truth. Thomas D'Oyley's Spanish Grammer appears in the stationers' register, entered to John Wolfe in October 1590. It is likely that D'Oyley knew of Perceval's impending publication and in fact rushed to print before his competitor. While it is quite possible that D'Oyley helped Perceval with the Latin in his edition, it seems unlikely that he gave up his efforts as readily as Perceval implies. Similarly, although Perceval does not acknowledge Corro in his list of sources, he included every word in the appended dictionary to the Spanish Grammer in the Bibliotheca Hispanica, borrowing both the Spanish words and the English definitions.

${ }^{16}$ There is no evidence that his fluency pre-dated this position, though some knowledge of Spanish certainly would help explain his appointment. 
Leicester likely met Atye in May 1572 when the university sent Atye to attend Leicester, the chancellor "durante tempore parlimenti." ${ }^{17}$ In fact, he was probably sent to protect the university's interests in a long-term battle with the city of Oxford, following the university's request to Leicester for parliamentary representation in March 1571. Leicester had also heard of Atye through Tobias Matthew, Leicester's chaplain whom he had placed in an oratorship at Oxford during Atye's time as a student there. Appointed in November 1569, Matthew deputized Atye in 1570. When Matthew resigned the oratorship Leicester named Atye his successor. ${ }^{18}$ The Bodleian's Rawlinson manuscripts detail much of what is known about Atye's time at Oxford before he joined Leicester's retinue. It is clear that he was operating as a very proficient scholar and prominent member of the university, but it is equally clear that in so doing he was preparing himself for a life concerned with the court. Scholarly debate surrounds the date Atye's service under Leicester commenced. Rosenberg suggests that Atye was appointed in 1580 in succession to Gabriel Harvey. Rosenberg's argument, which is based on Atye's own correspondence, is followed by Gustav Ungerer in his description of Atye in A Spaniard in Elizabethan England (1955:150). This date has since been pushed back by scholars. Most recently Simon Adams has argued convincingly that Atye was probably in Leicester's service as early as 1574 (Adams 1993:133), citing sights Atye's 1574 endorsement of a series of Leicester's letters beginning with a letter from 26 June to Guzman de Silva. ${ }^{19}$ What has evaded discussion is the significance of the date Atye's service to Leicester commenced as an indicator of the beginning of Leicester's interest in Spain. As discussed above, Burghley began to warn Elizabeth regarding Spain as early as 1569, but he only seems to have begun actively creating anti-Spanish propaganda in 1582. If Leicester's association with Atye pre-dates Burghley's first pamphlets by nearly a decade, it is an indication that Leicester's interest in language study pre-dates Burghley's campaigns (rather than following in its footsteps as the publication of Reglas in 1586 might suggest). In all

\footnotetext{
${ }^{17}$ Oxford, Bodleian Library, MS Rawlinson D 837, fol. 36.

${ }^{18}$ Oxford, Bodleian Library, MS Rawlinson D. 837, fol. 37-38v.

${ }^{19}$ London, British Library, Nero BVII, folio 179. Later letters from this series address Senior de Lumbres (Galba BXI, folio 246), John Strum (Harleian Mss. 692, folio 102), and Isabelle de La Touche (Titus B VII, folio 52).
} 
likelihood, Burghley and Leicester's conflict was on-going, beginning with the circulation of Spanish letters by Burghley in 1569, followed by translations by Atye throughout the 1570s. Atye's endorsement is found in countless Spanish letters as well as in reports received by Leicester regarding various campaigns in the Low Countries. ${ }^{20}$ There is abundant manuscript evidence that under Leicester Atye was engaged in making war seem attractive: British Library Additional Manuscript 48084 and British Library Additional Manuscript 48116 are both letters from Leicester's agents in the Netherlands, witnessed by Atye, reporting on the success of the English troops. These surviving letters idealize war, and are clearly intended for circulation at court as witnesses to English dominance. Yet although under Leicester Atye enthusiastically reported English successes against the Spanish in the Netherlands, his work never took a tone of propaganda: in fact, Atye's letters provide optimistic reports of the state of an ongoing English conflict. Only after Leicester's death, when Atye joined Essex's retinue, did he turn his attention towards projects that more explicitly condemned the Spanish. ${ }^{21}$ However, by the close of the decade and following the sack of Cadiz, even Burghley had moved away from this traditional

\footnotetext{
${ }^{20}$ Barbary Company Records, Oxford, Christ Church College, MS Evelyn 155 and 248. See also Willian (1959:188-190).

${ }^{21}$ The Earl of Essex, himself desperate for war with Spain, had his own relationship with Leicester's Spanish secretaries, particularly with Arthur Atye. Upon Leicester's death Atye began to translate Antonio Perez's Relaciones, a vitriolic work by the Spanish exile condemning the cruelty of the Spanish court. After struggling to find employment Atye eventually joined the household of the Earl of Essex; Antonio Perez also resided at Essex House. Atye sent his English translation of Perez's Relaciones on to Anthony Bacon on 27 March 1595 with the request that he amend the work where he saw fit. Atye's tone regarding the Spanish changed significantly under his new patron. Presentation copies of the translation were sent to many prominent members of the pro-war party, including the Earl of Southampton, Lord Henry Howard, Lord Mountjoy, Sir Robert Sidney, Anthony and Francis Bacon and Henry Watton. As inflammatory as the book was intended to be, Atye's translation stayed relatively true to the original text. Trained first as a scholar and only later as a secretary, Atye avoided creating strong propaganda. Furthermore, his translation was produced relatively quickly following the printing of Perez's work: translating the work no doubt proved sufficiently challenging in the time he had without editorially expanding the work. The translation represented Atye's largest and apparently final work. The Relaciones set the stage for Essex's campaign against Cadiz the following year. Atye's translation represented one of Essex's several desperate but ultimately unsuccessful attempts to enthuse the English for a war with Spain.
} 
mode of propaganda, as he too adopted the dictionary as a means of instructing English relations with Spain.

\section{Lord Burghley, John Minsheu, Richard Perceval, and the Dictionarie of Spanish and English}

Although he joined Burghley's secretariat late in his career, Richard Perceval proved one of Burghley's most influential secretaries. More than any of the lexicographers working under Leicester, Perceval clearly understood that the dictionary could be used as a propaganda tool. Although he tried to make the dictionary's power of persuasion clear to the Earl of Essex, it was only when he entered the Cecils' service that Perceval's work achieved its potential. Perceval did his best to capitalize on the widespread interest in vernacular language learning that dominated in England at the beginning of the last decade of the $16^{\text {th }}$ century. Following the publication of Antonio del Corro's The Spanish Grammer, an interest in learning Spanish developed around court. Unlike many Spanish speaking scholars, Perceval was never attached to either university: upon returning from self-imposed exile in Spain after an unfavourable marriage he taught at the Merchant Taylors' School for several years, and likely during this time he produced the Bibliotheca Hispanica (Healy 2010). The original Bibliotheca Hispanica reflects Perceval's hopes to align himself with Essex as a secretary or supported scholar. The Bibliotheca's dedication uses a language of chivalry and congratulates Essex on his bold military victories. Although Perceval credited Essex with exactly the chivalric character he desired, Essex does not seem to have taken much interest in him. Regardless of the pro-war tone of the introduction to the first edition of the Bibliotheca Hispanica Perceval was only a few years from joining Burghley's retinue of secretaries and spies. ${ }^{22}$ Perceval ends the dedication of this first edition by

\footnotetext{
${ }^{22}$ In his first edition of the Bibliotheca Hispanica Perceval created exactly the chivalric rhetoric around Essex that became increasingly important to the earl over the course of his career. Perceval addresses his work to "the right honourable Robert Earl of Essex [...] [to] increase of honour of heroicall vertues." Perceval repeatedly refers to the earl's "valour" and in so doing creates a work that is distinctly political. Yet though Perceval declares that Essex "employed [him]selfe so honorablie against the Spanyards in Flanders, Spayne, and Portugal gained an immortall memorie with all
} 
promising to polish his dictionary until it meets his audience's needs and expectations, a promise which indeed comes to fruition under Lord Burghley in the next decades with the oversight of John Minsheu.

Minsheu's version of Perceval's Bibliotheca, which he entitled $A$ Dictionarie in Spanish and English, transforms Perceval's work into a discursive dictionary, but more than this, into a decidedly political work. Minsheu's dictionary functioned as a language guide, including instructions on pronunciation and grammar. There is evidence of Burghley's politics reflected throughout Minsheu and Pereval's collaboration. Although the introduction from Minsheu is a relatively straightforward explanation of the work and a call for patronage, the work itself reflects Burghley's politics. The instructive dialogues which comprise nearly half the work are both averse to Spain and against war with Spain. In their 1599 volume, Minsheu and Perceval emphasize the "evill" of the Spanish terrain, characterizing it as both impassable and fraught with lying peasants (returning to the cultivation of distrust that was a trope of Walsingham's pamphlets) (Minsheu 1599:35). Minsheu's dictionary presents Spain as a fortress of natural obstacles, making an invasion seem impossible and Essex's 1596 campaign appear foolhardy. The work takes an entirely different tone than the original Bibliotheca Hispanica. In another dialogue a speaker explains that the Spanish go either "ala guérra, o a un monastéro, o a la hórca," and thus in a single sentence depicts the Spanish as cruel, warring, and Catholic (Minsheu 1599:39). A particularly interesting edition of the Copie held in the British Library seems to refer to Minsheu's dictionary, which the reader of this copy likely used as a means of approaching some of the contents of the work. On a blank sheet opposite the first page of the work the reader has inscribed an address in Latin, "Have mercy on the Spanish and survive still," and further declares "Praeda licet Minseus non sit satis ampla Philippo Ampla Satis Mundo Praeda Philippus crit" ["although Minsheu is not a large enough prey for Philip, Philip is a large enough prey for the world"], implying that nothing achieved in war with Spain could equal the loss incurred in such a war (A copie of the letter 1588). The reader seems to pun on the word "mundus", substituting a reference to

posteritie and might perhaps encounter with them againe upon like occasion," Essex misses his opportunity to utilize Perceval's work. 
Minsheu but spelling the word "Minseus", bringing together his means of accessing the work with his reaction to the work.

During his administrative career Burghley collected what may have been the largest Spanish library in Tudor England (Ungerer 1965:229). Ungerer's work documents the extent of the library, and demonstrates that while Burghley worked to foster a fear of Spain, he was himself familiar with many aspects of Spanish culture beyond the content of his propaganda. The collection was far from utilitarian. Burghley owned several editions of Amadis de Gaula and Amadis de Grecia, as well as various other romances and classical works. It is thus not surprising that once Burghley felt war with Spain had been averted he took an interest in creating a dictionary that would substantially improve English interest in and access to Spanish (whilst still mediating this access with an appropriate bias) (Ungerer 1965:229). Though Burghley's collection was likely motivated by a sense that his precise knowledge would help his defence of England, through it he became one of the most well-read Spanish scholars in Elizabethan England. Ironically it was Leicester, who was probably unable to read Spanish, who cultivated a study of the language in England by producing a community of Spanishspeaking scholars at Oxford. These Oxonian scholars opened the door for the printing of Spanish books in Elizabeth's England as they cultivated an interest in the language in students and a demand for Spanish books at the university, leading to Antonio del Corro's Reglas in 1586. Leicester's scholarly sponsorship projects led inadvertently to one of the largest scale soft-diplomacy projects of the $16^{\text {th }}$ century, dramatically increasing English familiarity with Spanish literature. The combined effect of the work of both the secretaries under Burghley and the scholars under Leicester created an English understanding of Spain at the turn of the $17^{\text {th }}$ century.

\section{References}

Adams, Simon 2002. Leicester and the Court: Essays on Elizabethan Politics. Manchester: Manchester University Press.

— 1993. "The Papers of Robert Dudley, Earl of Leicester: II The Atye-Cotton Collection." Archives XX (90): 131-144.

Aguilar, Juan de Jáuregui 1582. A True Discourse of the Assault Committed Upon the Person of the Most Noble Prince, William Prince of Orange. London: Thomas Charde and William Broome. 
Alexander, Gordon 2004. "Corro, Antonio del (1527-1591)." Oxford Dictionary of National Biography. Oxford: Oxford University Press.

Anon 1588. A copie of the letter sent out of England to Don Bernardin de Mendoza Ambassador in France for the King of Spaine. London: Vautrollier for Richard Field.

Anon 1596. A Libell of Spanish Lies: Found at the Sack of Cales, Discoursing the fight in the West Indies. London: John Windet.

Anon 1588. A Packe of Spanish Lyes Sent Abroad in the World: First printed in Spaine in the Spanish Tongue. London: Christopher Barker.

Anon 1588. Orders Set Downe by the Duke of Medina, Lord General of the Kings Fleet, to be observed in the voyage towards England. London: Thomas Orwin for Tomas Gilbert.

Bazan, Alvaro de 1600. The Opinion of Don Alvero Bacan, Marques of Santa Cruz, and high Admirall of Spaine, touching the armie of Sir Francis Drake.

Béze, Théodore de 1588. Ad Serenissimam Elizabetham Angliae Reginam Teodor. Beza. London: G. Bishop and R. Newbury.

Corro, Antonio del 1590. The Spanish Grammer. London: John Wolfe.

Crespin, Jean 1581. Lexicon Græcolatinum. London: Henry Binneman.

Devereux, Robert 1596. Declaracion de las causas que han movido la Magestad de la Reyna d'Ynglaterra, a embiar un'armada real, para defensa de sus Reynos y Senorios contra las fuercas del Rey d'Espana. London: Christopher Barker.

Foster, Joseph 1891. Alumni Oxonienses. Oxford: Parker and Co.

Googe, Barnabe 1579. The Proverbs of the noble and woorthy souldier Sir James Lopez de Mendoza, Marques of Santillana, with a Paraphrase of D. Peter Diaz of Toledo. London: Richard Watkins.

Haynes, Samuel 1740. A Collection of state papers [...] left by WIlliam Cecill, Lord Burghley. London: William Bowyer.

Healy, Simon. "Perceval, Richard (c. 1558-1629)." Oxford Dictionary of National Biography. Oxford: Oxford University Press.

Howard, Robert Earl of Essex and Charles 1596. A Declaration of the Just Causes Mooving the Queenes Majestie to Send a Navie and Armie to the Seas and towards Spaine. London.

Lea, James 1589. An Answer to the Untruthes Published in Spaine. London: J.Jackson for T. Cadman.

MacCaffrey, Wallace T. 2010. "Cecil, William, first Baron Burghley (1520/211598)." Oxford Dictionary of National Biography. Oxford: Oxford University Press.

Minsheu, John 1599. A Dictionarie in Spanish and English. London: Edmund Bollifant. 


$$
\text { (G) ederi } 21 \text { (2011) }
$$

Murdin, William 1759. A Collection of State Papers relating to affairs in the reign of Elizabeth from 1571 to 1596: transcribed from original papers and other authentic memorials left by W. Cecill Lord Burghley, and reposited in the library at Hatfield House. Ed. Samuel Hayes. London: William Bowyer.

Percyvall, Richard 1591. Bibliotheca Hispanica. London: John Jackson for Richard Watkins.

R. de M, Don F. 1589. Repuesta y desengaño contra las falsedades publicadas e impresas en Espana. London: Arnold Hatfield.

Randall, Dale B.J. 1963. The Golden Tapestry. A Critical Survey of Non-chivalric Spanish Fiction in English Translation (1543-1657). Cambridge: Cambridge University Press.

Rosenberg, Eleanor 1955. Leicester, Patron of Letters. New York: Columbia University Press.

Ungerer, Gustav 1956. Anglo-Spanish Literary Relations in Tudor Literature. Madrid: Artes Graficas Clavileño.

— 1965. "The Printing of Spanish Books in Elizabethan England." The Library $\mathrm{XX} / 3 \cdot 177-229$

- 1974. A Spaniard in Elizabethan England: The Correspondence of Antonio Perez's Exile. London: Tamesis Books Limited.

Willan, T.S. 1959. Studies in Elizabethan Foreign Trade. Manchester: Manchester University Press.

Withals, John 1579. A short dictionary most profitable for young beginners: the thyrde time corrected and augmented with dyuers phrases by Levvis Euans. London: Thomas Purfoote.

How to cite this article:

Crummé, Hannah Leah. "The Impact of Lord Burghley and the Earl of Leicester's Spanish-Speaking Secretariats." SEDERI 21 (2011): 7-27.

Author's contact: hannah.crumme@kcl.ac.uk 